Indonesian Journal of EFL and Linguistics

Vol. 5 No. 2, 2020

eISSN: 2503-4197, pISSN: 2527-5070

www. indonesian-efl-journal.org

\title{
The Strengths and Weaknesses of Extensive Reading using Wattpad; Students' Perceptions
}

\author{
Intan Permatasari \\ Sebelas Maret University \\ e-mail: Ipermatasari5794@gmail.com \\ Agus Wijayanto \\ Muhammadiyah University of Surakarta \\ e-mail: agus.abdn@gmail.com \\ Diah Kristina \\ Sebelas Maret University \\ e-mail: diahkristina@staff.uns.ac.id
}

\begin{abstract}
:
This study aims to explore the strengths and weaknesses of extensive reading using Wattpad platform based on students' perceptions. Extensive reading allows students to have more variation in their reading materials as they can read authentic texts from various sources that it is actually applied outside the class room for most people consider it as joyful reading. The advancement of technology over the times enables people to do many activities online, including extensive reading activity. Hence, Wattpad is believed to provide enormous free and paid reading materials that can support extensive reading for the students. To achieve the objectives, this study is in the form of case study. The data were collected through in-depth interview with the participants. The participants were two undergraduate students majoring English Education from two different universities in Indonesia. The participants were selected purposively because they were known to have been doing extensive reading activity on Wattpad for a quite long time, specifically for five years. The research findings showed several strengths of using Wattpad for extensive reading such as Wattpad gives
\end{abstract}


students numerous and various sources of reading materials; extensive reading on Wattpad is a fun and enjoyable experience; extensive reading on Wattpad is more practical than using printed-books; extensive reading on Wattpad is money-saving; the reading materials on Wattpad have good quality contents; extensive reading through Wattpad improves students English's skills unconsciously as well as the reading habit. Meanwhile, there are several weaknesses of extensive reading using Wattpad according to students such as; similarities in the reading materials sometimes make them boring to read; using the platform for a certain long time can potentially cause tired eyes; there are other distractions that can disrupt the extensive reading activity.

Keywords: extensive reading, students' perceptions, wattpad

\section{INTRODUCTION}

It has been long recognized that extensive reading allows students to have more variation in their reading materials because they can read authentic texts from various sources such as newspaper, journals, tabloids, articles, books, novels, short stories, magazines and web pages and that it is actually applied outside the class room for most people consider it as joyful reading (Harmer, 2007). Research studies show that extensive reading is effective in increasing reading speed and comprehension. It appears to lead to substantial vocabulary learning and learners show their development in spelling and vocabulary knowledge. It is also reported that extensive reading enhance students' affective domain such as motivation and attitude to read (Shen, 2008).

The advancement of technology over the times enables people to do many activities online, including extensive reading activity. Additionally, the presence of Internet connection allows learners to gain access to a huge amount of authentic materials to make English learning more enjoyable (Dang, 2011). There are quite many online reading platforms available on the internet such as Wattpad, Google Books, Glose, Tumblr, Goodreads, and so on, which enable their users to read extensively online. These platforms allow its users to choose what to read based on their interest and preferences. These platforms, therefore, seem to gain more popularity nowadays. For example, Wattpad claims to have an audience of more than 70 million users in 2019. Its users are free to use the platform to write and read extensively, as well as directly interact with the writers and share their opinions with fellow readers. Learners who read extensively on Wattpad are provided with abundant reading materials in various genres which they can choose based on their personal interests. Therefore, this makes Wattpad a potential platform to do extensive reading activities outside the classroom.

Although available in over 50 languages, $77 \%$ of its content is written in English. With this massive amount of users, the researcher is interested in finding out the strengths and weaknesses of doing extensive reading activities on Wattpad by exploring the students' perceptions towards it. Perception is a person's thought about something that 
they learn to measure how they behave towards something, whether they agree or not about that method or about something that they learn (Hong et al., 2003).

There are previous relevant studies related to this present study. However, none of the studies explores students' perceptions towards extensive reading specifically using Wattpad platform. Arifuddin (2018) conducted a thesis entitled "Students' Perception in the Impact of Extensive Reading Course". The study was in a form of a case study which observed the students' perceptions towards an extensive reading class which was conducted in a state university in Indonesia. The finding of the study reveals that Extensive Reading approach boosts students' interest in increasing their reading. It also builds students awareness in reading either in class or beyond classroom until it turns into their habits to read more and improve their reading level. Sanubari (2018) conducted a qualitative study entitled "Students' Perception on the Online Extensive Reading". The study aimed to find out the benefits of online extensive reading which was is done independently by Indonesian university students as well as its challenges. The results of the study show that the students' perceived online extensive reading as beneficial in helping them in terms of reading activities, as well as improving students' English skill in vocabulary and grammar knowledge. However, some challenges were also found by the students in doing extensive reading itself. Students lost interest in reading for some reasons, for example the reading material is too much. And also the student had problem when they read through the screen, some students said that it made their eyes tired.

To sum up, the researcher identifies the research problem as follow: What are the strengths and weaknesses of extensive reading using Wattpad platform according to Students' Perceptions?

\section{LITERATURE REVIEW}

\subsection{Extensive Reading}

Experts have defined Extensive Reading differently. Extensive Reading in Foreign language is a process of acquiring new language which is not the learner's mother tongue, through words, sentences and text by reading numerous books and that students are motivated to read for pleasure. It is not a big surprise that students reading several self-selected books in a short time will progress in reading and will become more confident in reading (Yildirim, 2014).

Frazier \& Brown (2001) states that extensive reading is the reading activity which aims to get general understanding of a longer text. It is usually performed outside the classroom. It is often called "pleasure reading", "free voluntary reading", "sustained silent reading", and "self-selected reading". Reading is done for pleasure without adding any comprehension test afterwards. The students are allowed to choose the materials they read depending on their interest. The use of dictionary is not recommended because the purpose of the extensive reading is to gain general understanding of the text. Therefore, it is not necessary for the students to understand each word. 
Additionally, according to Guide to Extensive Reading published by the Extensive Reading Foundation in 2011 as cited in Uden (2013), Extensive Reading on the other hand, means reading some materials for pleasure outside the classroom. When the students read extensively, they are practicing the skill of reading by reading for information - reading a story book for example with the purpose of enjoying the reading without consciously knowing they are learning.

\subsection{Wattpad}

Wattpad was co-founded in 2006 by the two Canadian engineers and co-workers Allen Lau and Ivan Yuen as an online community of writers and readers which they call as a platform for aspiring and experienced authors, allowing them to publish their work, get feedback and connect with other writers and readers (Ramdarshan Bold, 2018). Wattpad is therefore based on user-generated contents and has also been described as the "YouTube for stories (without video)" (Ramdarshan Bold, 2018). Furthermore, it combines all the affordances of both social networks and publishing platforms.

Wattpad is a very interesting digital environment with a large amount of potential for schools and learning. First of all, Wattpad provides the opportunity to reflect on the value of reading for young people (Scolari et al., 2018). Scolari in 2020 also states the main potential of the platform from the educational point of view is, that Wattpad brings students closer to the world of reading and writing through a purely informal channel based on peer-to-peer relationships.

Wattpad also provides enormous free and paid reading materials that can support extensive reading for the students. The platform offers 21 stories genres in total that its users can select based on their own interest. The stories genres include adventure, fantasy, historical fiction, horror, humor, science fiction, non-fiction, urban, thriller, and so on. Because Wattpad is a platform that allows its users both read and write, it has writers from various countries who write stories in different languages. However, the users can select the language of the stories that they prefer. Stories written in English are enormously available for the students to read. Some popular stories that are not written in English have also been translated in English to gain more readers.

\subsection{Students' Perceptions}

Perception is a person's thought about something that they learn to measure how they behave towards something, whether they agree or not about that method or about something that they learn (Hong et al., 2003). It means that a student has their opinion towards something from the teaching learning process and how they respond to it.

Ried in Nichols (Staudacher, 2008) defines perception as the process of justification of the beliefs on a certain object. In this process, students might give arguments to what they see as the way they perceive the things. Moreover, the beliefs will lead them to accept something as it is.

Walgito (2010) also determines three interrelated components of perception as follow; Cognitive component refers to knowledge, beliefs or thoughts based on information 
which is related to some objects. Affective component refers to the emotional dimension of attitude, that is, emotions are related to some objects. The object here is felt as pleasant or unpleasant. Behavior component or conative component involves predisposition to act or behave towards an object.

\section{RESEARCH METHODOLOGY}

\subsection{Participants}

The participants of the study were two undergraduate students who were selected purposely. The two participants are students from two different universities in Indonesia, majoring English education. These two participants were selected because they were known to have done extensive reading activity outside the classroom using Wattpad platform for a quite long time for more than two years.

\subsection{Instruments}

The research instrument used in this study is an interview consisting several questions related to the research problem. The interview questions were formed based on the three components of perceptions defined by Walgito and Ahmadi (2013). The researcher did an in-depth interview with the participants to gain adequate data to analyze.

\subsection{Data Analysis Procedures}

The data of this study were analyzed by using interactive model proposed by Miles, Hubberman, and Saldana (2014). Firstly, the researchers collected the data through an in-depth interview. Secondly, the researcher reduced the collected data by selecting the main data and losing the unimportant data. Then, the researcher showed the data in the form of word description. The last was drawing a conclusion. The researchers verified the data and made the initial conclusion to answer the research question.

\section{FINDINGS}

\subsection{Students' Perceptions of Extensive Reading with Wattpad}

Students' perceptions are categorized based on three components of perceptions by Walgito in 2010 as follow;

\subsubsection{Cognitive}

In the cognitive component, perceptions refer to knowledge, opinions, or beliefs of the participants toward doing extensive reading using Wattpad platform. In terms of knowledge, both the participants have known what Wattpad is. Both participants reveal they are able to use the platform for extensive reading activities. When questioned about what they knew about Extensive Reading and Wattpad, they answered very similarly. Below are some of the transcript of the interview with the participants: 
Intan Permatasari, Agus Wijayanto, Diah Kristina

"I know extensive reading is the activity of reading for pleasure based on my level of comprehension and when I do it, I'm allowed to select the reading materials on my own based on my personal interest." (1A)

"What I know about extensive reading is that it is an activity which enables me to read for pleasure, not intentionally to study. It's a very fun activity I usually do because I get to select the reading materials on my own based on my personal interest and my level of comprehension, it makes reading activity less stressful because I'm not pressured by anybody." (1B)

Both participants understand the concept of extensive reading in where its goals is to read for pleasure. When doing extensive reading, they choose their own reading materials based on their personal interest and their level of comprehension.

"Wattpad is an online platform or an application which I can access on my computer and mobile phone. It is a platform which provides its users a place to write and read for free. I've been using Wattpad since I was in high school. I think it's my fifth year of using it. It provides me with a lot of interesting reading materials in various genres and languages." (2A)

"What I know about Wattpad is that it is an online reading and writing platform that can be accessed from computer or mobile phone. It is a very interesting platform which provides us with numerous free and paid reading materials in many different genres. It's a very good platform for people who love reading for pleasure." (2B)

Both participants agree that Wattpad is an online reading platform that can be accessed from their computers or mobile phones which enables them to do extensive reading because it provides them with a lot of reading materials in various genres that they can select based on their personal interest.

"Yes, I use Wattpad for extensive reading. The amount of stories published on Wattpad is numerous and that makes it a good place for me to read extensively because there is always another new story after I finish one. There's always something to read on Wattpad." (3A)

"Yes, I think Wattpad is a great place to do extensive reading activities because as I mentioned previously, it has a large amount of reading materials in different genres that I can select. I have a lot of options of what to read on the platform." (3B)

Both participants agree that Wattpad is a good platform to do extensive reading activities because it has numerous sources of various reading materials in different genres which can support their extensive reading activities, especially reading for pleasure outside the classroom. 
The Strengths and Weaknesses of Extensive Reading using Wattpad

\subsubsection{Affective Component}

Affective component refers to feeling or emotional aspects which are not mediated by thinking. Anchored from the data obtained from the interview. Both participants have positive perceptions towards using Wattpad as a platform to do extensive reading.

"I find extensive reading with Wattpad as a fun experience. I like and enjoy the activity as well as the platform because it makes reading more fun and less stressful. Compared to printed books, often I can't bring my printed novels everywhere because my bag is already full of school books and I have to deal with the risk of losing them or leaving them somewhere. The presence of Wattpad really overcomes this problem. Often I get bored waiting for my next class for hours, luckily I have Wattpad on my phone, so I could kill time with reading on it." (4A)

Participants A show positive feeling in using Wattpad for extensive reading. She finds the activity on the platform is a fun experience that makes reading more fun and less stressful. This feeling that she perceives is also related to the practicality of the platform. With Wattpad, she is able to do extensive reading anywhere without having to bring heavy printed books.

"Extensive reading with Wattpad is a very fun experience. I like both the activity and the platform. It is very interesting and it gives me a better reading habit. Before I found the platform, I used to save money to afford a book that caught my attention in the bookstore. Now, after I found the platform, I could save more money and sometimes when I go to the bookstore, I saw rows of books on the new arrival shelf and I'll be like 'Oh... I have read that book on Wattpad for free. It's really fun. I love it." (4B)

Participants B also show positive feeling towards using Wattpad for extensive reading activities. She states the extensive reading activities she does on the platform gives her a better reading habit. She also likes the platform because she does not have to spend a lot of money on printed books anymore because the platform allows her to read for free.

However, when asked about whether there are some things that they do not like when doing extensive reading on Wattpad, both the participants argue that some of the reading contents are boring and quite similar to one another.

"I often found stories from different authors with similar plot and characterization. I get that when there is a newly published story which gains popularity, other authors may get inspired and then they also publish the same thing. I think it's very boring to keep reading that type of stories. " (5A)

Indonesian Journal of EFL and Linguistics, 5(2), 2020 
Intan Permatasari, Agus Wijayanto, Diah Kristina

"I think... because everyone can publish stories on Wattpad, not all the stories are actually well-written. I found stories with the exact same plot, just with different characters' names. Some stories have boring plots too because they're probably written by nonprofessionals. What I'm saying is I don't always find a good reading material on Wattpad." (5B)

Aside from the positive feelings towards doing extensive reading on Wattpad, both participants also mention that there are things that make the activity on the platform less enjoyable such as the apparent similarity in plots as well as characterizations of the stories that they read, even though they are published by different authors. Participant B also adds that not all stories on Wattpad are well-written because everyone even the non-professional authors can write on the platform. Therefore, it is not always effortless to find an extensive reading material on the platform.

When asked about the quality of reading materials, specifically the authors' writing skill in terms of grammar and word selections. Both the participants state that they do not have problems with authors' grammars and words selections. In other words, both participants have positive feelings toward the quality of the authors' writing in terms of grammar and words selection.

"Maybe because I read the ones written by English native speakers, I hardly found grammar mistakes in the writing. I don't have problems with word selections too because most of the times, it is already suitable with my English comprehension. I understand what I read. The words aren't difficult to understand." (6A)

'So far, I don't think I have problems with authors' grammars and words selection. I usually pick the ones written by the native authors when I want to read English stories." (6B)

\subsubsection{Conative Component}

Conative component refers to actions or the behavior of the participants towards using Wattpad for extensive reading. According to the data gained from the in-depth interview, it is known that both participants have positive actions and behavior regarding using Wattpad for extensive reading activities.

"Nobody pressured me to read on Wattpad. I discovered the platform myself and I motivated myself to read on the platform for my entertainment. Later on, I found out that by reading extensively on the platform, I feel like my English skill is improving unconsciously. Therefore, I personally think it's good for me to continue doing the activity on the platform. It also gives me a better reading habit." (7A) 
The Strengths and Weaknesses of Extensive Reading using Wattpad

"Firstly, I used Wattpad to read for fun in my spare time only. It turned out I enjoy the activity a lot, so I just keep on doing it until it becomes some good habit. Now, I cannot spend a day without reading at least two pages of a book in my Wattpad library. I also think extensive reading on Wattpad enhances my level of English comprehension unconsciously." (7B)

Both participants use Wattpad for extensive reading, specifically reading for pleasure. They find the activity beneficial in terms of improving their reading habit and their English comprehension unconsciously. Both participants state they will continue doing the extensive reading activities on the platform.

When questioned about if there are any inconveniences which affect their actions and behavior regarding reading extensively on Wattpad, they stated;

"Sometimes, I have to stop reading when I found the type of stories which I explained before. The ones with similar plots and characterization. I have to stop for a while and try to find another one which is more interesting." (8A)

"There's not a lot inconvenience. It's just because I read from my mobile phone, sometimes my eyes get very tired after a few hours and sometimes I get distracted with notifications from other applications on my phone. It is annoying when I have to stop reading midway because somebody is calling me. Also because I mostly use my mobile phone to access the platform, it often drains my phone battery. There are times when I am enjoying what I read so much and I don't realize I've spent five hours on it, my phone suddenly dies due to low power of the battery. Sometimes, I have to stop reading because of it." (8B)

Both participants show changes in their behavior towards extensive reading on Wattpad. Participant A often stops her activity of extensive reading on the platform when she finds out that the story she currently read have apparent similarities in plot and characterization with the one that she has read previously. However, participant $\mathrm{B}$ have different perceptions. The inconveniences that influence her behavioral changes towards extensive reading on Wattpad are the technical factors. She mentioned that reading on the platform for a certain amount of hours could potentially make her eyes tired. She also reveals that sometimes she has to stop her activity on the platform because she gets distracted with notifications from other applications on her mobile phone. According to participant B, the platform also can drain the mobile phone's battery power. Sometimes she needs to stop reading because her mobile phone is getting shut down all of the sudden due to the low power of the battery caused by the platform. 
Intan Permatasari, Agus Wijayanto, Diah Kristina

\subsection{Strengths and Weaknesses of Extensive Reading through Wattpad}

After gaining the students' perceptions towards extensive reading activities through Wattpad platform generally, the researcher draws strengths and weaknesses of using Wattpad for extensive reading according to the students' perceptions. The researcher categorizes the strengths and weaknesses as the following;

Table 1: Strengths of Extensive Reading through Wattpad

\begin{tabular}{ll}
\hline Students' perception & Strength \\
\hline "It provides me with a lot of interesting & Numerous and various reading \\
reading materials in various genres and & materials \\
languages" - Cognitive component (2A) & \\
"It is a very interesting platform which & \\
provides us with numerous free and paid & \\
reading materials in many different & \\
genres." - Cognitive component (2B) & \\
\hline
\end{tabular}

"I like and enjoy the activity as well as the platform because it makes reading more fun Fun and enjoyable experience and less stressful." - Affective component (4A)

"Extensive reading with Wattpad is a very fun experience. I like both the activity and the platform." - Affective Component (4B)

Compared to printed books, often I can't bring my printed novels everywhere because my bag is already full of school books and I have to deal with the risk of losing them or leaving them somewhere. The presence of Wattpad really overcomes this problem. Often I get bored waiting for my next class for hours, luckily I have Wattpad on my phone, so I could kill time with reading on it. - Affective Component (4A)

"Now, after I found the platform, I could save more money and sometimes when I go to the bookstore, I saw rows of books on the new arrival shelf and I'll be like 'Oh... I have read that book on Wattpad for free." Affective Component (4B)

"I hardly found grammar mistakes in the writing. I don't have problems with word selections too because most of the times, it 
The Strengths and Weaknesses of Extensive Reading using Wattpad

is already suitable with my English comprehension." - Affective Component (6A)

"I found out that by reading extensively on the platform, I feel like my English skill is improving unconsciously." - Conative Component (7A)

"I also think extensive reading on Wattpad enhances my level of English comprehension unconsciously" - Conative Component (7B)

"It also gives me a better reading habit." Conative Component (7A)

"I enjoy the activity a lot, so I just keep on doing it until it becomes some good habit." - Conative Component (7B)

Table 2: Weaknesses of Extensive Reading through Wattpad

\begin{tabular}{|c|c|}
\hline Students' perception & Weakness \\
\hline $\begin{array}{l}\text { "I often found stories from different authors } \\
\text { with similar plot and characterization. I get } \\
\text { that when there is a newly published story } \\
\text { which gains popularity, other authors may get } \\
\text { inspired and then they also publish the same } \\
\text { thing. I think it's very boring to keep reading } \\
\text { that type of stories." - Affective Component } \\
\text { (5A) }\end{array}$ & $\begin{array}{l}\text { Similarities in the reading } \\
\text { materials sometimes make them } \\
\text { boring to read. }\end{array}$ \\
\hline $\begin{array}{l}\text { "I think... because everyone can publish } \\
\text { stories on Wattpad, not all the stories are } \\
\text { actually well-written. I found stories with the } \\
\text { exact same plot, just with different characters' } \\
\text { names. Some stories have boring plots too } \\
\text { because they're probably written by non- } \\
\text { professionals." - Affective Component (5B) }\end{array}$ & \\
\hline $\begin{array}{l}\text { "It's just because I read from my mobile } \\
\text { phone, sometimes my eyes get very tired after a } \\
\text { few hours." - Conative Component (8B) }\end{array}$ & Tired eyes \\
\hline $\begin{array}{l}\text { "I get distracted with notifications from other } \\
\text { applications on my phone" }- \text { Conative } \\
\text { Component }(8 \mathrm{~B})\end{array}$ & $\begin{array}{l}\text { Distractions from other } \\
\text { notifications }\end{array}$ \\
\hline
\end{tabular}


Intan Permatasari, Agus Wijayanto, Diah Kristina

"I mostly use my mobile phone to access the platform, it often drains my phone battery" -

Battery power-draining

Conative Component (8B)

\section{DISCUSSION}

There are two major scopes of findings which are addressed namely students' perceptions towards extensive reading on Wattpad and the strength and weaknesses of using Wattpad for extensive reading. From the in-depth interview, it is revealed that the participants have positive perceptions towards extensive reading on Wattpad. Their perceptions were constructed by the three elements of the perception itself namely cognitive, affective, and conative element.

In term of cognitive component, both participants reveal they are able to use the platform for extensive reading activities. Both participants understand the concept of extensive reading in where its goals is to read for pleasure. When doing extensive reading, they choose their own reading materials based on their personal interest and their level of comprehension. This is relevant with the principles of extensive reading as proposed by Day \& Bamford (2002) in which learners select what they want to read. Both participants agree that Wattpad is a good platform to do extensive reading activities because it has numerous sources of various reading materials in different genres which can support their extensive reading activities, especially reading for pleasure outside the classroom.

In term of affective component, both the participants agree that extensive reading on Wattpad is a fun experience that makes reading more fun and less stressful. The participants also have positive perception towards the practicality of the platform to use for extensive reading. It is also revealed that the extensive reading activities the platform gives the participants a better reading habit. This result is in line with Arifuddin (2018) who found that Extensive Reading increases students' interest in increasing their reading as well as builds students awareness in reading either in class or beyond classroom until it turns into their habits to read more and improve their reading level. . It is also obtained that using the platform for extensive reading is more money-saving. Apart from the positive feelings towards doing extensive reading on Wattpad, both participants also mention several causes that possibly make the activity on the platform less enjoyable such as the apparent similarity in plots as well as characterizations of the stories that they read, even though they are published by different authors. Therefore, it actually takes efforts to find extensive reading materials on the platform with great quality content, especially stories plots. Regarding the reading materials, specifically the authors' writing skill in terms of grammar and word selections. Both the participants state that they do not have problems with authors' grammars and words selections. In other words, both participants have positive feelings toward the quality of the authors' writing in terms of grammar and words selection. 
In term of conative component, both participants use Wattpad for extensive reading, specifically reading for pleasure. They perceive the activity as beneficial in terms of improving their reading habit and their English comprehension unconsciously. This is in line with The Guide to Extensive Reading published by Extensive Reading Foundation (2011) and Uden (2013) which states that when the students read extensively, they are practicing the skill of reading by reading for information reading a story book for example with the purpose of enjoying the reading without consciously knowing they are learning. This result is also in line with Arnold (2009)who found that online extensive reading program not only successfully improved the learners' reading ability but also increased their motivation for reading and raised their confidence to read. Both participants also agree to continue using the platform for extensive reading. However, both participants reveal that they show changes in their behavior towards extensive reading on Wattpad for particular factors such as the apparent similarities in plot and characterization in reading materials even though they are written by different authors. There are also some other inconveniences that influence participants' behavioral changes towards extensive reading on Wattpad such as reading on the platform for a certain amount of hours could potentially lead to tired eyes. Distractions from notifications from other applications and how the platform drains the power-battery of the mobile phone also disrupt participants' extensive reading activity on the platform. This result is in line with Huang (2013) who conducted a study on students' perceptions towards e-book reading, the study found similar weaknesses on the activity. Sanubari (2018) also found similar weaknesses on her study which aimed to explore students' perceptions towards online extensive reading.

According to the data in the form of students' perceptions gained from the in-depth interview with both participants, there are seven strengths of using Wattpad for extensive reading. Wattpad gives students numerous and various sources of reading materials; extensive reading on Wattpad is a fun and enjoyable experience; extensive reading on Wattpad is more practical than using printed-books; extensive reading on Wattpad is money-saving; the reading materials on Wattpad have good quality contents; extensive reading through Wattpad improves students English's skills unconsciously as well as the reading habit. There are four weaknesses of extensive reading through Wattpad revealed by the participants as follow; similarities in the reading materials sometimes make them boring to read; using the platform for a certain long time can potentially cause tired eyes; there are distractions from other notifications that disrupt the extensive reading activity on the platform; the platform drains the battery-power. However, overall, it is found that students tend to show more positive attitude towards their extensive reading activity on the platform.

\section{CONCLUSION}

In conclusion, the results of this study show students' positive perceptions towards extensive reading using Wattpad platform. Students perceive that Wattpad is a good platform to do extensive reading activities because it has numerous sources of various 
reading materials in different genres which can support their extensive reading activities, especially reading for pleasure outside the classroom. However, apart from the positive perceptions, there are also several strengths and weaknesses of extensive reading using Wattpad revealed by the students. Students mentioned seven strengths of using Wattpad for extensive reading; Wattpad gives students numerous and various sources of reading materials; extensive reading on Wattpad is a fun and enjoyable experience; extensive reading on Wattpad is more practical than using printed-books; extensive reading on Wattpad is money-saving; the reading materials on Wattpad have good quality contents; extensive reading through Wattpad improves students English's skills unconsciously as well as the reading habit. Additionally, there are four weaknesses of extensive reading using Wattpad mentioned by the students such as; similarities in the reading materials sometimes make them boring to read; using the platform for a certain long time can potentially cause tired eyes; there are distractions from other notifications that disrupt the extensive reading activity on the platform; the platform drains the battery-power.

\section{REFERENCES}

Arifuddin, A. (2018). Students' Perception In The Impact of Extensive Reading Course. In ثبثبثب

Arnold, N. (2009). Online Extensive Reading For Advanced Foreign Language Learners: An Evaluation Study. Foreign Language Annals. Https://Doi.Org/10.1111/J.1944-9720.2009.01024.X

Dang, X. (2011). Factors Influencing Teachers' Use Of Ict In Language Teaching: A Case Study Of Hanoi University, Vietnam. International Conference "Ict For Language Learning."

Day, R., \& Bamford, J. (2002). “Top Ten” Principles For Teaching Reading - First Page Only. Reading In A Foreign Language.

Frazier, S., \& Brown, H. D. (2001). Teaching By Principles: An Interactive Approach To Language Pedagogy. Tesol Quarterly. Https://Doi.Org/10.2307/3587655

Harmer, J. (2007). The Practice Of English Language Teaching Fourth Edition. In Cambridge: Pearson Longman.

Hong, K. S., Ridzuan, A. A., \& Kuek, M. K. (2003). Students' Attitudes Toward The Use Of The Internet For Learning: A Study At A University In Malaysia. Educational Technology And Society.

Huang, H. Chou. (2013). E-Reading And E-Discussion: Efl Learners' Perceptions Of An E-Book Reading Program. Computer Assisted Language Learning. Https://Doi.Org/10.1080/09588221.2012.656313

Ramdarshan Bold, M. (2018). The Return Of The Social Author: Negotiating Authority And Influence On Wattpad. Convergence. Https://Doi.Org/10.1177/1354856516654459

Scolari, C. A., Masanet, M. J., Guerrero-Pico, M., \& Establés, M. A. J. (2018). 
The Strengths and Weaknesses of Extensive Reading using Wattpad

Transmedia Literacy In The New Media Ecology: Teens' Transmedia Skills And Informal Learning Strategies. Profesional De La Informacion. Https://Doi.Org/10.3145/Epi.2018.Jul.09

Shen, M. (2008). Efl Learners' Responses To Extensive Reading: Survey And Pedagogical Applications. The Reading Matrix.

Staudacher, A. (2008). Ryan Nichols, Thomas Reid's Theory Of Perception, Oxford: Oxford University Press, 2007. Xvi + 301pp, \$99 Hb. Isbn: 978-0199276912. . Journal Of Scottish Philosophy. Https://Doi.Org/10.3366/E1479665108000237

Uden, J. (2013). The Extensive Reading Foundation's Guide To Extensive Reading. Elt Journal. Https://Doi.Org/10.1093/Elt/Cct010

Walgito, B. (2010). Pengantar Psikologi Sosial. In Yogyakarta: Andi Ofset.

Yildirim, A. (2014) . The Benefits Of Extensive Reading For Foreign Language Acquisition. Grin Verlag 